\title{
Waldenström's macroglobulinemia - a review
}

\author{
Susana Coimbra ${ }^{1,2 *}$, Rafael Neves ${ }^{3}$, Margarida Lima ${ }^{4}$, Luís Belo ${ }^{1,3}$, Alice Santos-Silva $^{1,3}$ \\ ${ }^{1}$ Institute of Molecular and Cellular Biology (IBMC), University of Porto, Porto, Portugal. \\ ${ }^{2}$ CESPU, Institute for Research and Advanced Training in Health Sciences and Technologies, Gandra-PRD, Portugal. \\ ${ }^{3}$ Department of Biological Sciences, Biochemistry Laboratory, Faculty of Pharmacy, University of Porto, Porto, Portugal. \\ ${ }^{4}$ Santo António General Hospital, Centro Hospitalar of Porto, Porto, Portugal.
}

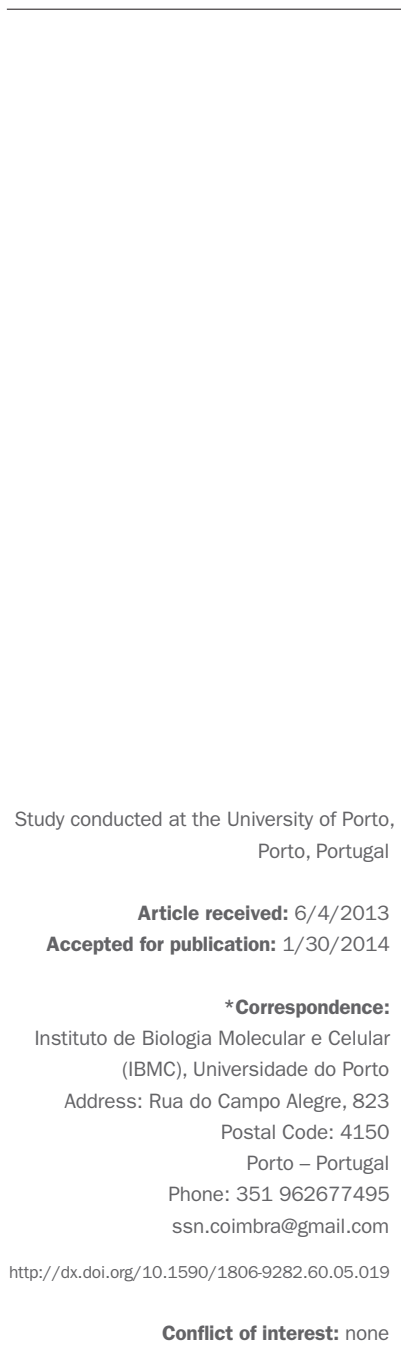

\section{SUMmARY}

Waldenström's macroglobulinemia (WM) is a lymphoproliferative disease of B lymphocytes, characterized by a lymphoplasmocytic lymphoma in the bone marrow and by IgM monoclonal hypergammaglobulinemia. It was first described in 1944 by Jan Gösta Waldenström, reporting two patients with oronasal bleeding, lymphadenopathy, anemia, thrombocytopenia, high erythrocyte sedimentation rate and serum viscosity, normal radiography and bone marrow infiltrated by lymphoid cells.

The WM is a rare disease with a typically indolent clinical course, affecting mainly individuals aged between 63 and 68 years. Most patients have clinical signs and symptoms related to hyperviscosity resulting from IgM monoclonal gammopathy, and/or cytopenias resulting from bone marrow infiltration by lymphoma. The differential diagnosis with other lymphomas is essential for the assessment of prognosis and therapeutic approach.

Treatment of patients with asymptomatic WM does not improve the quality of life of patients, or increase their survival, being recommended, therefore, their follow-up. For the treatment of symptomatic patients, alkylating agents, purine analogs and anti-CD20 monoclonal antibodies are used. However, the disease is incurable and the response to therapy is not always favorable. Recent studies have shown promising results with bortezomib, an inhibitor of proteasomes, and some patients respond to thalidomide. In patients with relapse or refractory to therapy, autologous transplantation may be indicated.

The aim of this paper is to describe in detail the current knowledge on the pathophysiology of WM, main clinical manifestations, diagnosis, prognosis and treatment.

Keywords: Waldenström's macroglobulinemia, hypergammaglobulinemia, IgM, lymphocytes B. prognosis.

\section{INTRODUCTION}

Waldenström's macroglobulinemia (WM), described in 1944 by Jan Gösta Waldenström, is a lymphoplasmacytic lymphoma (LPL) characterized by IgM monoclonal hypergammaglobulinemia and bone marrow infiltration. ${ }^{1}$

LPLs are rare and indolent cancers of mature B-lymphocytes, which predominantly involve the bone marrow and, less commonly, the spleen, lymph nodes, peripheral blood and other organs. ${ }^{1}$

\section{Epidemiology}

WM has an estimated incidence of 3 cases/million/year, accounting for about $2 \%$ of all hematological cancers. ${ }^{2}$
There is a higher incidence in individuals aged between 63 and 68 years. ${ }^{3}$ Approximately $60 \%$ of patients are men, and it is more common in caucasian indivuals. ${ }^{3}$ The average survival is 5 years, ${ }^{3}$ however, approximately $10 \%$ of patients survive up to 15 years. ${ }^{4}$ As the disease is mainly diagnosed in old age, about $50 \%$ of patients die due to comorbidities not related directly to WM. ${ }^{3}$

\section{Etiology}

Its etiology is unknown, but several studies suggest a possible causal relationship with autoimmune diseases, exposure to environmental factors and chronic antigenic 
stimulation, such as infection with the hepatitis $C$ virus $(\mathrm{HCV})$. Despite the high incidence of HCV infection in these patients, a statistically significant association between HCV infection and WM has not been found. ${ }^{5}$

In relation to familial predisposition, an association is estimated in $20 \%$ of cases. ${ }^{6,7}$ In first degree family relations there is a high risk of developing lymphoproliferative diseases, which is twenty times higher for WM/LPL. ${ }^{8}$

\section{Pathophysiology}

It is believed that WM originates in memory B-lymphocytes. ${ }^{9,10}$ These lymphocytes descend from B-lymphocytes that proliferate in the germinal centers of lymph nodes (post-germinal center B-lymphocytes), accumulating all the genetic changes that occur in these centers. Thus, in most cases, the neoplastic B cells present somatic hypermutation in the genes coding the hypervariable regions of the immunoglobulin heavy chains $\left(\mathrm{V}_{\mathrm{H}}\right.$ genes). ${ }^{11,12}$ However, in some cases, the neoplastic B-cells are derived from B-lymphocytes which have undergone somatic mutation outside of germinal centers. ${ }^{13}$ In other cases, there is no evidence of somatic mutations in the $\mathrm{V}_{\mathrm{H}}$ genes, which may indicate that they are derived from pre-germinal center B-lymphocytes, such as "virgin" B-lymphocytes. ${ }^{12}$

In relation to the mechanisms involved in the pathophysiology of WM, the blocking of immunoglobulin isotype switching and the role of cytokines is noteworthy.

Most malignant cells in WM express surface IgM and $\operatorname{IgD}$, suggesting an intrinsic incapacity to switch isotypes. ${ }^{13}$ This "block" may be related to the absence/dysfunction of the activation-induced cytidine deaminase (AID) enzyme, which is involved in somatic hypermutation and the immunoglobulin isotype switching process. ${ }^{11,13}$

Although isotype switching is rarely seen in WM, according to some studies it is possible that it occurs ex vivo and in vivo. Kriangkum et al. ${ }^{11}$ demonstrated that AID may be induced ex vivo, by stimulation with CD40L and interleukin-4 (IL-4). Another study showed the possibility of isotype switching occurring in vivo. ${ }^{14}$

Mast cells and various cytokines play an important role in the development of the disease..$^{15}$ Cytokines may be important for angiogenesis, increased bone resorption, proliferation, survival of malignant cells, and secretion of monoclonal IgM.

In WM, malignant B-lymphocytes express the receptor $\mathrm{CD} 27,{ }^{13}$ which can be found in the membrane of memory B-lymphocytes and in soluble form (sCD27) in high concentrations in the serum. ${ }^{15} \mathrm{sCD} 27$ activates bone marrow mast cells by binding to CD70. Activated mast cells secrete growth and survival factors for B-lymphocytes such as CD40L and APRIL (proliferation-inducing ligand), ${ }^{15}$ which may contribute to lymphoplasmocytoid differentiation of malignant cells in the bone marrow.

\section{Clinical symptoms}

The clinical presentation of WM varies. Most of the patients present clinical signs/symptoms related to IgM hypergammaglobulinemia and/or LPL infiltration in organs and tissues, especially bone marrow. However, some patients do not exhibit any clinical symptoms when diagnosis is made. ${ }^{16}$

Blood hyperviscosity determines hemorheological changes and is one of the most important characteristics of WM; however, it is observed in less than $15 \%$ of patients upon diagnosis. The large size of the monoclonal IgM molecule and its high concentration contribute to increased blood viscosity and vascular resistance, compromising the blood flow to oxygenate tissues. ${ }^{17}$

The main clinical manifestations associated with the hyperviscosity syndrome are bleeding (epistaxis, bleeding gums and gastrointestinal bleeding), ocular changes (papilledema, blindness, blurred vision and retinal changes: hemorrhage, exudates, dilatation and segmentation of the retinal veins, venous thrombosis), neurological changes (headache, dizziness, syncope, deafness, ataxia, diplopia, drowsiness and even seizures) and cardiac changes (heart failure)..$^{18}$

The symptoms of hyperviscosity generally manifest when the concentration of monoclonal IgM is greater than $5000 \mathrm{mg} / \mathrm{dL}$ or when the serum viscosity reaches $4-5$ $\mathrm{cP}$ (reference range: 1.4 to $1.8 \mathrm{cP}$ ). However, the serum viscosity is not always proportional to the concentration of IgM and its relationship to symptoms is not linear. ${ }^{16}$

Type I cryoglobulinemia (monoclonal IgM cryoglobulinemia) is associated with lymphoproliferative diseases such as WM, and is detected in approximately $20 \%$ of patients, while symptomatic in only $5 \%$ of cases. ${ }^{19}$ The precipitation of monoclonal IgM cryoglobulin is also responsible for some clinical symptoms, such as Raynaud's phenomenon, acrocyanosis, purpura and necrosis of body regions most exposed to the cold. It is also responsible for the development of distal symmetrical sensorimotor polyneuropathy or multiple mononeuropathy with axonal degeneration. ${ }^{20,21}$

Monoclonal IgM can cause platelet dysfunction by binding to IIIa and Ib glycoproteins on the surface of platelets or due to nonspecific interactions with platelets. ${ }^{9}$ It may also neutralize the activity of several coagulation factors (fibrinogen, prothrombin, factors V, VII, VIII, IX, $\mathrm{X}$, and Von Willebrand factor), ${ }^{9,22}$ triggering hemostatic 
disorders that are the source of hemorrhagic manifestations.

Monoclonal IgM may exhibit "cold agglutinin" activity, binding to erythrocyte antigens at a temperature lower than physiological temperature, determining the development of chronic cold antibody hemolytic anemia. This monoclonal immunoglobulin is generally IgM Kappa, which often interacts with I/i antigens on the surface of erythrocytes. ${ }^{23,24}$ Anemia manifests in less than $10 \%$ of patients and is generally associated with "cold agglutinins" levels above $1: 1000 .{ }^{25}$ The reduction in the temperature of blood flowing through the peripheral blood vessels favors the binding of IgM "cold agglutinins" to the surface of erythrocytes. ${ }^{26}$ This agglutination of erythrocytes in peripheral blood vessels is responsible for Raynaud's phenomenon, acrocyanosis and livedo reticularis, which is reversible when large blood circulation resumes.

Type II cryoglobulinemia (mono and polyclonal) is characterized by the deposition of monoclonal IgM-polyclonal IgG immunocomplexes at the level of blood vessels, with consequent activation of the complement. ${ }^{17}$ The main clinical manifestations are vasculitis, purpura, arthralgia, digital necrosis, Raynaud's phenomenon, peripheral neuropathy in lower limbs, renal impairment (proteinuria, hematuria, nephrotic syndrome), and liver impairment (hepatomegaly, liver dysfunction).

Around $20 \%$ of patients may be experiencing neurological symptoms at the time of diagnosis. The most frequent neurological disorder is a demyelinating distal symmetrical sensorimotor peripheral neuropathy, which manifests itself slowly and progressively, causing paresthesia and asthenia. About 50\% of these patients have myelin-associated glycoprotein antibodies (MAG anti-antibodies). ${ }^{27}$ These are generally monoclonal IgM kappa and are often involved in demyelinating neuropathies.

Monoclonal IgM can also connect nonspecifically to multiple antigens of the peripheral nerves, triggering axonal impairment. ${ }^{20,28}$

The biological function of various tissues and/or organs may be altered by the formation and deposition of monoclonal IgM aggregates, however, the clinical manifestations related to their deposition are not frequent.

The deposition of monoclonal IgM in the basal membrane of the epidermis is associated with bullous skin disease. ${ }^{29}$ If it occurs at the level of the dermis it contributes to the formation of papular-nodular lesions on the surface (Macroglobulinemia cutis). ${ }^{30,31}$ Some patients may have chronic urticarial erythema, fever and arthralgia (Schnitzler syndrome). ${ }^{32}$
The deposition of monoclonal IgM in the lamina propria and/or submucosa of the intestine can be associated with diarrhea, malabsorption and gastrointestinal bleeding. ${ }^{33}$

Renal failure is not very common; however, monoclonal IgM may accumulate in the renal glomeruli, forming subendothelial deposits that clog glomerular capillaries. ${ }^{34}$ In this case, there may be moderate but reversible proteinuria, being the majority of patients asymptomatic.

In primary or light chain amyloidosis (AL amyloidosis), amyloid fibrils may be deposited in the heart, kidneys, liver, lungs and peripheral nerves. ${ }^{20}$ Cardiac and pulmonary involvement is more frequent in patients with amyloidosis associated with monoclonal IgM. ${ }^{35,36} \mathrm{AL}$ amyloidosis may be related to the development of symmetrical or asymmetrical sensory-motor polyneuropathy. $\mathrm{Pa}$ tients experience pain, the sensation of "electric shocks" and thermal sensitivity in the lower limbs. AL amyloidosis may further affect the autonomic nervous system, causing diarrhea, hypotension, impotence and bladder dysfunction. $^{28}$

The deposition of amyloid A protein (AA amyloidosis) has been documented, although rare, ${ }^{37,38}$ and may occur in the kidneys and intestines, causing nephrotic syndrome and intestinal malabsorption. ${ }^{39}$

IgG and IgA hypogammaglobulinemia may occur simultaneously with monoclonal IgM hypergammaglobulinemia, which can contribute to recurrent respiratory tract infections, but its cause is not well understood and could be associated with alterations in the development of plasma cells and/or the production of immunoglobulins. ${ }^{40}$

LPL primarily involves the bone marrow, but the disease can reach the lymph nodes, spleen and liver, among other organs. Lymphoplasmocytoid/plasmacytic infiltration is responsible for asthenia, fatigue, recurrent fever, night sweats, weight loss, cytopenia, lymphadenopathy and organomegaly. ${ }^{17}$

Fatigue is one of the most common symptoms and is often associated with normocytic normochromic anemia; around $80 \%$ of symptomatic patients have moderate to severe anemia. ${ }^{27}$ Anemia is not only due to the change in medullary erythropoiesis. Other factors may contribute to its aggravation, such as gastrointestinal bleeding, hyperhemolysis, and hyperviscosity itself, which may cause a decrease in the erythropoietin synthesis. ${ }^{41}$ It should be noted that false anemia may be observed in some patients caused by the high concentration of monoclonal IgM, which contributes to the increase in plasma volume and consequent hemodilution. 
Extramedullary infiltration is uncommon, and may affect the articular and periarticular structures, gastrointestinal tract, lungs, kidneys, skin, eyes and central nervous system. ${ }^{17,27,42}$

The symptoms of malabsorption, diarrhea, obstipation or bleeding may indicate involvement of the gastrointestinal tract. ${ }^{43-46}$ Some patients have cellular infiltration at the pulmonary parenchymal level, ${ }^{47,48}$ being coughing the most common symptom, followed by dyspnea and chest pain. Renal infiltration has also been reported ${ }^{49}$ as well as cutaneous infiltration (maculopapular lesions, plaques or nodules) $)^{7,50}$ and infiltration of periorbital structures, such as the tear gland and retro-orbital lymphoid tissue (ocular tremors). ${ }^{51,52}$

The infiltration of malignant cells in the central nervous system is responsible for a rare neurological disorder called Bing-Neel syndrome. Associated symptoms are nystagmus, diplopia, vertigo, memory loss, mental confusion, motor dysfunction and eventually coma. ${ }^{17,53}$

\section{Diagnosis}

Table 1 presents the diagnostic criteria for WM. The detection of IgM monoclonal gammopathy is important for diagnosis, but the serum concentration presents a great variability between individuals. ${ }^{16}$

For diagnosis, a bone marrow biopsy is crucial to assess the extent of neoplastic infiltration, the infiltration pattern and cellular morphology. In WM, medullary infiltrate consists of a monoclonal cellular population of small B-lymphocytes, in different maturation stages: small lymphocytes, lymphoplasmocytoid lymphocytes and plasma cells.

The level of differentiation of the infiltrate is variable, ranging from lymphoplasmocytoid (47\% of cases), consisting of small cells and plasmacytoid lymphocytes, to lymphoplasmacytic (42\%), with predominantly small lymphocytes and plasma cells. The polymorphic state $(11 \%)$ is characterized by a broad spectrum of these many cells.

A high number of mast cells in the medullary infiltrate is frequent, and this finding may help in the differential diagnosis.

LPL may eventually evolve into a more aggressive form of lymphoma such as as diffuse large B-cell lymphoma. ${ }^{54}$ This evolution is accompanied by worsening of clinical symptoms, with development of profound cytopenia, organomegaly and extramedullary cellular infiltration. ${ }^{54}$

In the peripheral blood, plasmacytoid lymphocytes are sometimes observed, but leukemic symptoms are rarely observed.

Immunophenotyping should be interpreted simultaneously, verifying its consistency with the results of a bone marrow biopsy. In practice, IgM monoclonal gammopathy associated with the expression of IgM on neoplastic B-lymphocytes with a $\mathrm{CD}^{+} 9^{+}, \mathrm{CD} 20^{+}, \mathrm{CD} 5^{-}, \mathrm{CD} 10^{-}$ and $\mathrm{CD} 23$ phenotype and intertrabecular pattern of bone marrow infiltration is sufficient for the diagnosis of $\mathrm{MW}^{16}$ (Table 1). Nevertheless, the phenotypic characteristics are not always typical and in about $10-20 \%$ of cases positivity for CD5, CD10 or CD23 has been described. ${ }^{17.55,56}$ Other common phenotypic features which are not specific but may be useful for the differential diagnosis with other lymphoproliferative diseases are the expression of sIgD, CD22, CD79a, PAX5, Bcl2, FMC7, CD25 and CD27 and the absence of expression of BCL6, CD103, CD138, CD56 and CD75. Some of these markers are particularly useful for studying the bone marrow infiltrate in the bone biopsy through immunohistochemical and other studies for the immunophenotypic characterization of B-lymphocytes by flow cytometry.

TABLE 1 Clinical and laboratory characteristics of Waldenström's macroglobulinemia

IgM monoclonal gammopathy of varying concentration

Bone marrow biopsy: $\geq 10 \%$ infiltration by small B-lymphocytes with plasmacytoid/plasmacytic differentiation

Bone marrow biopsy: generally intertrabecular infiltration pattern

Immunophenotyping of B-lymphocytes: CD19+, CD20+, CD5, CD10, CD23, slgM+(monoclonal)

Other immunophenotypic characteristics of neoplastic B-lymphocytes: slgD ${ }^{+}, \mathrm{CD}_{2} 2^{+}, \mathrm{CD} 79 \mathrm{a}^{+}, \mathrm{PAX} 5^{+}, \mathrm{Bcl}^{+}, \mathrm{FMC7}^{+}, \mathrm{CD}^{2} 5^{+}, \mathrm{CD}^{2} 7^{+}, \mathrm{BCL6}^{-}$, CD103, CD138, CD56, CD75

Cytogenetic studies: over $50 \%$ of cases present deletions (del) $6 \mathrm{q}$

slgM - Surface immunoglobulin M.

Note: Immunophenotypic variations may occur. Other lymphoproliferative diseases, including marginal zone B-cell lymphoma, chronic lymphocytic leukemia and mantle cell lymphoma should be excluded. 
The assessment of the clinical status of patients involves several examinations and laboratory tests (Table 2).

When interpreting the results it is important to consider that some parameters could be altered because the monoclonal IgM may interfere in several measurements performed in automated analyzers, especially in the evaluation of HDL cholesterol, bilirubin, inorganic phosphate, LDL cholesterol, C-reactive protein, creatinine, glucose, urea, iron and calcium ions. ${ }^{27}$

\section{Differential Diagnosis}

It is fundamental to distinguish WM from other disorders that could be clinically confused with this disease.
Differential diagnosis (Table 3) is important for the exclusion of neoplasms potentially secreting monoclonal IgM and which can also present lymphocytes with lymphoplasmocytoid differentiation in the bone marrow. This group includes marginal zone lymphomas, ${ }^{57}$ chronic lymphocytic leukemia $\left(\mathrm{CD}^{+}, \mathrm{CD} 23^{+}\right)$, mantle cell lymphoma ( $\left.\mathrm{CD}^{+}, \mathrm{CD} 23^{-}\right)$, follicular lymphoma $\left(\mathrm{CD} 10^{+}\right)$and multiple myeloma $\left(\mathrm{CD} 138^{+}, \mathrm{CD} 38^{+}, \mathrm{CD} 56^{+}\right) . .^{17,57}$

The differentiation between symptomatic WM, asymptomatic WM and IgM monoclonal gammopathy of undetermined significance (MGUS) is important since the latter patients present risk of progression to symptomatic WM of $1.5 \% /$ year..$^{58,59}$ This differs from asymptomatic

\section{TABLE 2 Laboratory assessment in patients with clinical suspicion of Waldenström's macroglobulinemia}

\begin{tabular}{|c|c|}
\hline Laboratory exam & Clinical justification \\
\hline $\begin{array}{l}\text { Electrophoresis of serum proteins } \\
\text { Electrophoresis of urinary proteins ( } 24 \text {-hour urine) }\end{array}$ & $\begin{array}{l}\text { Detection of monoclonal gammopathy - homogeneous peak, high, narrow } \\
\text { base, usually in the area of gamma globulins }\end{array}$ \\
\hline Immunofixation of serum and urinary proteins & Characterize the immunoglobulin: heavy chain and light chain \\
\hline Bone marrow biopsy & $\begin{array}{l}\text { Assess the bone marrow infiltration by lymphocytes, the infiltration pattern } \\
\text { and cell morphology }\end{array}$ \\
\hline Erythrocyte sedimentation rate & Frequently raised \\
\hline Cytogenetic studies & $\begin{array}{l}\text { Differential diagnosis of other malignancies of B-lymphocytes secreting } \\
\text { monoclonal IgM }\end{array}$ \\
\hline $\begin{array}{l}\text { Blood test } \\
\text { - Reticulocyte count } \\
\text { - Concentration of haptoglobin, indirect bilirubin and lactate dehydrogenase } \\
\text { - Research, identification and quantification of "cold agglutinins" } \\
\text { - Direct Coombs Test and title of "cold agglutinins" }\end{array}$ & $\begin{array}{l}\text { Evaluation of thrombocytopenia and anemia, which is usually normocytic } \\
\text { and normochromic } \\
\text { Search autoimmune hemolytic anemia. Useful in patients with Raynaud's } \\
\text { syndrome, acrocyanosis or limb ulceration }\end{array}$ \\
\hline Serum viscosity & $\begin{array}{l}\text { Determine if the patient has signs and symptoms of hyperviscosity or } \operatorname{lgM} \\
\text { concentration }>4000 \mathrm{mg} / \mathrm{dL}\end{array}$ \\
\hline Eye examination - ophthalmoscopy & Justified in the event of changes in vision \\
\hline Urea, creatinine and transaminases (AST and ALT) & Evaluation of renal and hepatic function \\
\hline$\beta 2$-microglobulin & Relevant for prognosis \\
\hline $\operatorname{lgG}$ and $\lg A$ & Predisposition to respiratory infections \\
\hline ТTPa, TP, ТT & In patients with bleeding diathesis and a tendency to bruise \\
\hline $\begin{array}{l}\text { Detection and semi-quantification of anti-MAG, anti-SGPG, anti- } \\
\text { GM1, anti-sulfatide antibodies }\end{array}$ & $\begin{array}{l}\text { In patients with peripheral neuropathy, such as progressive symmetrical } \\
\text { numbness of the limbs, burning sensation and tingling, pain in the feet and } \\
\text { hands }\end{array}$ \\
\hline $\begin{array}{l}\text { Screening of AL amyloidosis - electrophoresis and immunofixation } \\
\text { of urinary proteins (24-hour urine) } \\
\text { Confirmation of AL amyloidosis test - abdominal fat aspirate }\end{array}$ & In suspected cases of AL amyloidosis \\
\hline Electromyography & In patients who have impaired motor function \\
\hline Computed tomography of the abdomen, trunk and pelvis & Detection of organomegaly (e.g. spleen, liver) and lymphadenopathy \\
\hline
\end{tabular}


TABLE 3 Differential diagnosis of Waldenström's macroglobulinemia (WM) (Adapted from Fonseca and Hayman 200776)

\begin{tabular}{|c|c|c|c|}
\hline Neoplasm & Immunophenotype & $\begin{array}{l}\text { Pattern of marrow infiltration and cell } \\
\text { morphology }\end{array}$ & Cytogenetic abnormalities \\
\hline $\begin{array}{l}\text { Waldenström's } \\
\text { Macroglobulinemia }\end{array}$ & 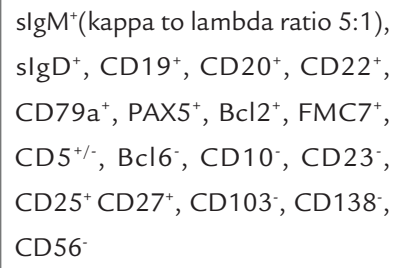 & $\begin{array}{l}\text { Generally intertrabecular; } \\
\text { Small lymphocytes with plasmacytoid } \\
\text { differentiation }\end{array}$ & $\begin{array}{l}\text { Most patients have a normal karyotype; } \\
\text { The most frequent cytogenetic alterations are } \\
6 q 21-23 \text { deletions }\end{array}$ \\
\hline Multiple Myeloma & 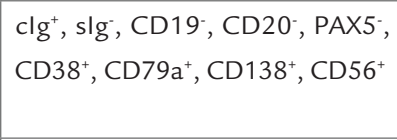 & $\begin{array}{l}\text { Nodular, diffuse, interstitial; } \\
\text { Plasma cells with different degrees of } \\
\text { maturation }\end{array}$ & $\mathrm{t}(11 ; 14)(\mathrm{q} 13 ; \mathrm{q} 32)$ \\
\hline $\begin{array}{l}\text { B-cell chronic } \\
\text { lymphocytic } \\
\text { leukemia }\end{array}$ & $\begin{array}{l}\text { slg }^{+} \text {(weak), CD43+ (weak), } \\
\mathrm{CD}^{+} 0^{+} \text {(weak), CD19+, CD23+, } \\
\mathrm{CD}^{+}, \mathrm{CD}^{+} 3^{+}, \mathrm{CD} 10^{-}, \mathrm{CD} 79 \mathrm{~b} / \\
\mathrm{CD} 22^{-}, \mathrm{FMC7}^{-} \text {, Cyclin D1 }\end{array}$ & $\begin{array}{l}\text { Nodular, interstitial, diffuse or mix of } \\
\text { all three; } \\
\text { Small lymphocytes with dense nucleus, } \\
\text { aggregated chromatin, no visible nucleoli } \\
\text { and reduced cytoplasm }\end{array}$ & $\begin{array}{l}\text { Del 13q14 ( } 50 \% \text { of cases); } \\
\text { Del 11q ( } 20 \% \text { of cases); } \\
\text { Trisomy of chromosome } 12 \text { ( } 20 \% \text { of cases); } \\
\text { Del 17p; } \\
\text { Presence of ZAP- } 70^{+} \text {(Tyrosine Kinase of } 70 \\
\text { Kda associated to the zeta chain of the T } \\
\text { lymphocyte receptor complex) }\end{array}$ \\
\hline $\begin{array}{l}\text { Mantle cell } \\
\text { lymphoma }\end{array}$ & 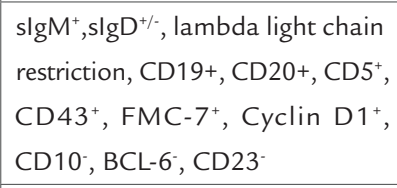 & $\begin{array}{l}\text { Variable infiltration pattern. } \\
\text { Lymphocytes are small or medium in } \\
\text { size with irregular nucleus }\end{array}$ & $\mathrm{t}(11 ; 14)(\mathrm{q} 13 ; \mathrm{q} 32)$ \\
\hline $\begin{array}{l}\text { Follicular } \\
\text { lymphoma }\end{array}$ & $\begin{array}{l}\mathrm{slg}^{+}, \mathrm{CD}_{10}^{+}, \mathrm{CD}^{+} 9^{+}, \mathrm{CD} 20+ \\
\mathrm{CD} 21^{+}, \mathrm{CD} 22^{+}, \mathrm{CD}^{+} \mathrm{a}^{+}, \mathrm{Bcl}^{-} \\
2^{+}, \mathrm{Bcl}-6^{+}, \mathrm{CD} 43^{-}, \mathrm{CD} 5, \mathrm{CD} 23 \\
\mathrm{CD}^{-} 3^{-}\end{array}$ & $\begin{array}{l}\text { Paratrabecular infiltration; } \\
\text { Centrocytes (small cells with "cleaved" } \\
\text { nuclei and reduced cytoplasm) and } \\
\text { centroblasts (large cells with round or } \\
\text { oval nuclei, vesicular chromatin, and } \\
\text { low basophilic cytoplasm) }\end{array}$ & $\mathrm{t}(14 ; 18)(\mathrm{q} 32 ; \mathrm{q} 21)(70-95 \%$ of cases $)$. \\
\hline $\begin{array}{l}\text { Extranodal } \\
\text { marginal zone } \\
\text { lymphoma, MALT }\end{array}$ & 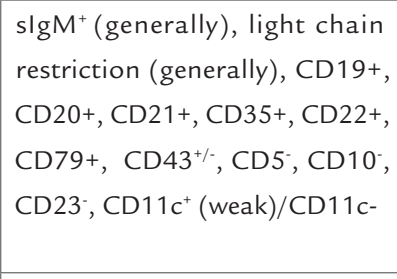 & Variable & $\begin{array}{l}\text { Trisomy } 3 \text { ( } 60 \% \text { of cases); } \\
\mathrm{t}(11 ; 18)(\mathrm{q} 21 ; \mathrm{q} 21)(25 \%-50 \% \text { of cases); } \\
\mathrm{t}(1 ; 14)(\mathrm{p} 22 ; \mathrm{q} 32) \\
\mathrm{t}(11 ; 18)(\mathrm{q} 21 ; \mathrm{q} 22) \\
\mathrm{t}(14 ; 18)(\mathrm{q} 32 ; \mathrm{q} 21) \\
\mathrm{t}(3 ; 14)(\mathrm{p} 13 ; \mathrm{q} 32)\end{array}$ \\
\hline $\begin{array}{l}\text { Nodal marginal } \\
\text { zone lymphoma }\end{array}$ & $\begin{array}{l}\text { Most lymphomas have a similar } \\
\text { immunophenotype to MALT } \\
\text { lymphoma, others have a similar } \\
\text { immunophenotype to splenic } \\
\text { marginal zone lymphomas }\end{array}$ & Variable & $\begin{array}{l}\text { Trisomy } 3 \text {; } \\
\mathrm{t}(11 ; 18)(\mathrm{q} 21 ; \mathrm{q} 21)\end{array}$ \\
\hline $\begin{array}{l}\text { Splenic marginal } \\
\text { zone lymphoma }\end{array}$ & 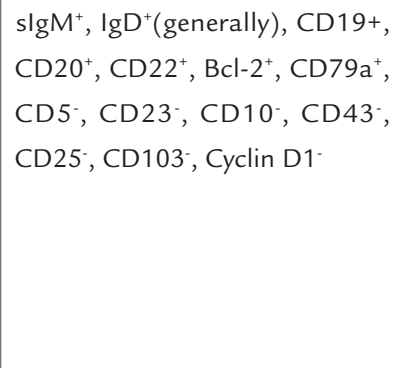 & Nodular, interstitial & $\begin{array}{l}\text { Chromosomal gains: 3q ( } 30-40 \% \text { of cases), } 5 q \\
(28 \%), 12 q(24 \%), 20 q(24 \%), 9 q(21 \%), 4 q \\
(17 \%) ; \\
\text { Trisomy } 3(17 \%) ; \\
\text { Del } 7 q ; \\
\text { Del } 6 q \text { and Del } 17 p \text { - Genetic alterations } \\
\text { associated with clinical progression of the } \\
\text { disease }\end{array}$ \\
\hline
\end{tabular}

clg - cytoplasmic immunoglobulin, slg, surface immunoglobulin; MALT, mucosa-associated lymphoid tissue. 
WM due to the lower concentration of monoclonal IgM $(<3 \mathrm{~g} / \mathrm{dL})$ and absence of bone marrow infiltration $(<10 \%)$. The risk of progression from asymptomatic to symptomatic WM is $6 \% /$ year, and only $55 \%$ of these patients will show progression within 5 years ${ }^{3}$.

\section{Prognosis of symptomatic WM}

The International Prognostic Staging System for Waldenström Macroglobulinemia adopts five variables that correlate with poor survival of patients under treatment: age> 65 years, $\beta 2$-microglobulin concentration $>3 \mathrm{mg} / \mathrm{L}$, platelets count $\leq 100 \times 10^{9} / \mathrm{L}$, monoclonal IgM concentration $>7000 \mathrm{mg} / \mathrm{dL}$, and hemoglobin concentration $\leq 11.5 \mathrm{~g} /$ $\mathrm{dL}{ }^{60}$ The absence or presence of one or more prognostic factors categorizes the patient into 3 risk levels: low ( $0-1$ risk factor, excluding age), intermediate ( 2 risk factors and age > 65 years) or high (more than 3 risk factors). ${ }^{60}$

Based on the degree of risk, it is possible to estimate the average/overall survival. In patients at low risk, the average survival time is 12 years, and treatment should involve low toxicity, preserving quality of life. The use of this system in symptomatic patients that are candidates for treatment enables tailoring treatment to the patient, taking into account the estimated average survival.

In a recent study, high concentrations of lactate debydrogenase (> $250 \mathrm{IU} / \mathrm{L}$ ) were also seen as a poor prognosis factor, especially in high risk patients. ${ }^{61}$

\section{TREATMENT}

Clinical decision to prescribe therapy takes into account different factors such as patient age, clinical manifestations, prognostic factors, quality of life and patient survival potential, the risk/benefit and cost/benefit of treatment, effectiveness and side effects.

The treatment of asymptomatic patients does not improve their quality of life and survival; ${ }^{3}$ biannual clinical observation is the recommended option in these cases if hematologic function is preserved. ${ }^{3}$ There is a study that suggests bimonthly/quarterly follow-ups during the first year after diagnosis and, if remaining stable, monitoring should be quarterly/half-yearly in the following years. ${ }^{62}$

Patients with WM are candidates for treatment if they have clinical evidence of aggressive disease progression or if they have had clinical and laboratory manifestations associated with WM, such as lymphadenopathy or splenomegaly, symptoms of hyperviscosity, severe peripheral neuropathy, AL amyloidosis (resulting in tissue deposition of light immunoglobulin chains), cryoglobulinemia, autoimmune hemolytic anemia, hemoglobin concentration $<10 \mathrm{~g} / \mathrm{dL}$ and/or platelet count $<100 \times 10^{9} / \mathrm{L}^{63}$
In fact, the choice of treatment is a critical option and should not be taken so as to limit future options, since all patients will inevitably present relapses after initial treatment, requiring treatment. ${ }^{3}$ Age, the presence of cytopenia, the need to control the disease and the possibility of autologous stem cell transplantation should be considered in the approach to treatment. ${ }^{63}$

First-line therapy includes alkylating agents, purine analogs and monoclonal anti-CD20 antibodies. ${ }^{63}$ Treatment with alkylating agents may cause cytopenias and myelosuppression, and should be avoided in patients that are candidates for autologous transplantation. ${ }^{63,64}$ Purine analogs may be responsible for the development of myelodysplasia and acute myeloid leukemia. ${ }^{63.65}$

The Mayo Clinic has developed a therapeutic approach adapted to the clinical characteristics of the patient. ${ }^{3}$ Most symptomatic patients are treated with Rituximab as monotherapy or combined with chemotherapy. Monotherapy is recommended in symptomatic patients with moderate hematological impairment, in patients with neuropathy associated with the IgM autoantibody, and in cases of hemolytic anemia resistant to corticosteroids. ${ }^{3}$

Rituximab is an IgG1 anti-CD20 monoclonal antibody. The connection to the CD20 receptor on B-lymphocytes activates the complement cascade, leading to the formation of the membrane attack complex that induces cell lysis. ${ }^{66}$ This antibody also activates natural killer cells by binding to receptors for the Fc fragment of $\operatorname{IgG}(\mathrm{Fc} \gamma \mathrm{R})$, leading to cell lysis. The fragments of complement component $\mathrm{C} 3$, together with rituximab, are recognized by the membrane of macrophages, binding to receptors for complement component $\mathrm{C} 3$ and $\mathrm{F} c \gamma \mathrm{R}$ receptors, respectively, and activating phagocytosis. ${ }^{66,67}$ The genetic polymorphism of $\mathrm{F} \gamma \mathrm{R}$ receptors may condition the treatment response, ${ }^{68}$ and a correlation has been observed between polymorphisms at position 158 of the FcyRIIIa (CD16) receptor and the response to rituximab.

At the start of rituximab treatment, some patients have a paradoxical and often transient increase in serum concentrations of IgM (IgM flare), which can persist for up to 4 months and is not indicative of treatment failure. ${ }^{69,70}$ The underlying mechanism remains unclear, but two hypotheses have been proposed - release of intracellular IgM resulting from rituximab-mediated cell death and cell signaling mediated by binding to $\mathrm{CD} 20 .^{71}$

In patients requiring urgent control of the disease, plasmapheresis is indicated if they have clinical manifestations of moderate to severe hyperviscosity, cryoglobulinemia and cytopenias caused by the action of the monoclonal IgM autoantibody ${ }^{62,3}$ Usually 2 to 3 plasmapheresis sessions 
are necessary to reduce the concentration of IgM from 30 to $60 \%$. The sessions should be repeated daily until symptoms subside or until normalization of serum viscosity. Subsequent treatment should be started quickly, as the concentration of IgM will return to its initial level after 4 to 5 weeks. ${ }^{62}$ These patients should be treated with the dexamethasone, rituximab and cyclophosphamide (DRC) combination regimen. The main reasons for choosing this regimen in these patients are the good treatment tolerance, reduced myelosuppression and the lack of toxicity for stem cells. ${ }^{3,65}$

In patients with relapses or who are refractory to therapy, the choice of treatment depends on the first-line treatment already utilized, the quality/duration of the response and other variables, such as age, tolerance to initial treatment, and also the possibility of the patient being a candidate for stem cell transplantation. ${ }^{63}$

The reuse of the first-line treatment is recommended if the response to initial treatment was maintained without maintenance for at least 12 months. Otherwise, another first-line agent or combination therapy should be used. ${ }^{63}$

In patients with short-term remission or resistance to initial treatment, therapy with a drug of different pharmacological class as monotherapy or combined is recommended. In association therapy, a regime using rituximab, fludarabine and cyclophosphamide is highlighted; however, the latter should be avoided in younger patients and candidates for autologous stem cell transplantation. ${ }^{63}$

The use of bortezomib (proteasome inhibitor) has proven promising, as well as alemtuzumab (anti-CD52 monoclonal antibody) datalidomida, enzastaurin (protein kinase $\mathrm{C}$ inhibitor), everolimus (inhibitor of mammalian target of rapamycin - mTOR) and perifosine (Akt inhibitor). ${ }^{62,64,72}$ Histone deacetylase inhibitors treatment agents, such as panobinostat (LBH589), new proteasome inhibitors, such as carfilzomib, human anti-CD20 monoclonal antibody, such as ofatumumab, and alkylating agents, such as bendamustine, also seem to be promising agents. ${ }^{72}$

Transplantation of hematopoietic stem cells is indicated in younger patients with multiple recurrences or who have been refractory to previous treatments. ${ }^{62}$ Autologous transplantation is associated with improved survival and long periods without disease progression, and should be considered in all candidate patients presenting relapse. ${ }^{3}$

The concentration of monoclonal IgM is one of the parameters most commonly used among the criteria for assessing response to treatment. However, this biomarker is not always reliable, since its concentration can be affected by the treatment itself. ${ }^{62}$
Taking into account the criteria for treatment response, complete response is observed when IgM serum levels normalize with complete disappearance of IgM monoclonal protein (by immunofixation), histological evaluation of the bone marrow shows no evidence of disease, and all symptoms, lymphadenopathy and/or organomegaly are resolved. Partial response is considered in a scenario of $\geq 50 \%$ decrease in the monoclonal IgM serum concentration, decreased lymphadenopathy/organomegaly and absence of new symptoms and/or signs of active disease on electrophoresis of serum proteins compared to the baseline values. A minimal response is observed when the reduction in electrophoresis of monoclonal IgM is $<50$ but $\geq 25 \%$, and no new symptoms and/ or signs of active disease are observed. The stable disease corresponds to cases in which the value of monoclonal IgM relative to baseline undergoes a reduction of $<25 \%$ and increases $<25 \%$, with no progression of lymphadenopathy/organomegaly and cytopenias, and no significant clinical signs or symptoms. The disease is considered progressive when there is an increase in the detectable amount of protein electrophoresis and monoclonal IgM serum levels $\geq 25 \%$ (confirmed by a second assessment) or progression of complications resulting from the disease or symptoms attributed to WM. ${ }^{73}$

The concentration of sCD27 and assessment of the amount of monoclonal free light chains have been presented as potential biomarkers for laboratory monitoring of therapy ${ }^{74,75}$ The investigation of alternative biomarkers is essential for a more reliable and less invasive clinical evaluation.

\section{Resumo}

Macroglobulinemia de Waldenström - uma revisão.

A macroglobulinemia de Waldenström (MW) é uma doença linfoproliferativa dos linfócitos B, caracterizada por um linfoma linfoplasmocítico na medula óssea e por hipergamaglobulinemia monoclonal de tipo IgM. Foi descrita pela primeira vez em 1944, por Jan Gösta Waldenström, que descreveu dois doentes com hemorragia oronasal, adenopatias, anemia, trombocitopenia, velocidade de sedimentação eritrocitária e viscosidade sérica elevadas, radiografia óssea normal e medula óssea infiltrada por células linfoides.

A MW é uma doença rara com um percurso clínico normalmente indolente, atingindo principalmente os indivíduos com idades entre 63 e 68 anos. A maioria dos doentes apresenta sintomas e manifestações clínicas relacionadas com a 
hiperviscosidade, resultante da gamopatia monoclonal IgM e/ou com as citopenias, resultantes da infiltração medular pelo linfoma. O diagnóstico diferencial com outros linfomas é essencial para a avaliação do prognóstico e a abordagem terapêutica.

O tratamento dos doentes com MW assintomática não melhora a qualidade de vida do doente nem aumenta a sua sobrevivência, recomendando-se o acompanhamento clínico. Para o tratamento dos doentes sintomáticos, são usados agentes alquilantes, análogos das purinas e anticorpos monoclonais anti-CD20. No entanto, a doença é incurável e a resposta à terapêutica nem sempre é favorável. Estudos relativamente recentes mostram resultados promissores com o bortezomibe, um inibidor dos proteossomas, e alguns doentes respondem à talidomida. Nos doentes com recidivas ou refratários à terapêutica, pode-se indicar o transplante autólogo.

O objetivo deste trabalho é descrever, de forma detalhada, o conhecimento atual sobre a fisiopatologia da MW, as principais manifestações clínicas, o diagnóstico, o prognóstico e o tratamento.

Palavras-chave: macroglobulinemia de Waldenström; hipergamaglobulinemia; IgM; linfócitos B; prognóstico.

\section{References}

1. Campo E, Swerdlow S, Harris N, Pileri S, Stein H, Jaffe E. The 2008 WHO classification of lymphoid neoplasms and beyond: evolving concepts and pratical applications. Blood. 2011;117: 5019-32.

2. Vos JM, Minnema MC, Wijermans PW, Croockewit S, Chamuleau ME, Pals ST, et al. Guideline for diagnosis and treatment of Waldenstrom `s macroglobulinaemia. Neth J Med. 2013;71:54-62.

3. Ansell SM, Kyle RA, Reeder CB, Fonseca R, Mikhael JR, Morice WG, et al. Diagnosis and management of Waldenstrom macroglobulinemia: Mayo stratification of macroglobulinemia and risk-adapted therapy (mSMART) guidelines. Mayo Clin Proc. 2010;85:824-33.

4. Kyle RA, Greipp PR, Gertz MA, Witzig TE, Lust JA, Lacy MQ, et al. Waldenström's macroglobulinaemia: a prospective study comparing daily with intermittent oral chlorambucil. Br J Haematol. 2000;108:737-42.

5. Leleu X, O'Connor K, Ho AW, Santos DD, Manning R, Xu L, et al. Hepatitis $\mathrm{C}$ viral infection is not associated with Waldenström's macroglobulinemia. Am J Hematol. 2007;82:83-4.

6. Renier G, Ifrah N, Chevailler A, Saint-Andre JP, Boasson M, Hurez D. Four brothers with Waldenstrom's macroglobulinemia. Cancer. 1989;64:1554-9.

7. Treon SP, Hunter ZR, Aggarwai A, Ewen EP, Masota S, Lee C, et al. Characterization of familial Waldenstrom`s macroglobulinemia. Ann Oncol. 2006;17:488-94.

8. Kristinsson SY, Björkholm M, Goldin LR, McMaster ML, Turesson I, Landgren O. Risk of lymphoproliferative disorders among first-degree relatives of lymphoplasmacytic lymphoma/Waldenström macroglobulinemia patients: a population-based study in Sweden. Blood. 2008;112:3052-6.

9. Merchionne F, Procaccio P, Dammacco F. Waldenstrom's macroglobulinemia. An overview of its clinical, biochemical, immunological and therapeutic features and our series of 121 patients collected in a single center. Crit Rev Oncol Hematol. 2011;80:87-99.

10. Sahota SS, Forconi F, Ottensmeier CH, Provan D, Oscier DG, Hamblin TJ, et al. Typical Waldenstrom macroglobulinemia is derived from a B-cell arrested after cessation of somatic mutation but prior to isotype switch events. Blood. 2002;100:1505-7.
11. Kriangkum J, Taylor BJ, Strachan E, Mant MJ, Reiman T, Belch AR, et al. Impaired class switch recombination (CSR) in Waldenström macroglobulinemia (WM) despite apparently normal CSR machinery. Blood. 2006;107:2920-7.

12. Kriangkum J, Taylor BJ, Treon SP, Mant MJ, Belch AR, Pilarski LM. Clonotypic $\mathrm{IgM} \mathrm{V} / \mathrm{D} / \mathrm{J}$ sequence analysis in Waldenstrom macroglobulinemia suggests an unusual B-cell origin and an expansion of polyclonal B cells in peripheral blood. Blood. 2004;104:2134-42.

13. Kriangkum J, Taylor B, Reiman T, Belch A, Pilarski L. Origins of Waldenström's macroglobulinemia: does it arise from an unusual b-cell precursor? Clin Lymphoma. 2005;5:217-9.

14. Martín-Jiménez P, García-Sanz R, Sarasquete ME, Ocio E, Pérez JJ, González $\mathrm{M}$, et al. Functional class switch recombination may occur in vivo in Waldenström macroglobulinaemia. Br J Haematol. 2007;136:114-6.

15. Ho AW, Hatjiharissi E, Ciccarelli BT, Branagan AR, Hunter ZR, Leleu X, et al. CD27-CD70 interactions in the pathogenesis of Waldenstrom macroglobulinemia. Blood. 2008;112:4683-9.

16. Johnson SA, Birchall J, Luckie C, Oscier DG, Owen RG. Guidelines on the management of Waldenstrom macroglobulinaemia. Br J Haematol. 2006;132:683-97.

17. Dimopoulos MA, Kyle RA, Anagnostopoulos A, Treon SP. Diagnosis and management of Waldenstrom's macroglobulinemia. J Clin Oncol. 2005;23:1564-77.

18. Gertz MA, Fonseca R, Rajkumar SV. Waldenstrom's macroglobulinemia. Oncologist. 2000;5:63-7.

19. Merlini G, Baldini L, Broglia C, Comelli M, Goldaniga M, Palladini G, et al. Prognostic factors in symptomatic Waldenstrom's macroglobulinemia. Semin Oncol. 2003;30:211-5.

20. Dimopoulos MA, Panayiotidis P, Moulopoulos LA, Sfikakis P, Dalakas M. Waldenström's macroglobulinemia: clinical features, complications, and management. J Clin Oncol. 2000;18:214-26.

21. Garcia-Bragado F, Fernandez JM, Navarro C, Villar M, Bonaventura I. Peripheral neuropathy in essential mixed cryoglobulinemia. Arch Neurol. 1988;45:1210-4.

22. Lüftl M, Sauter-Jenne B, Gramatzki M, Eckert F, Jenne L. Cutaneous macroglobulinosis deposits in a patient with IgM paraproteinemia/incipient Waldenström macroglobulinemia. J Dtsch Dermatol Ges. 2010;8:1000-3.

23. Pruzanski W, Shumak KH. Biologic activity of cold-reacting autoantibodies (first of two parts). N Engl J Med. 1977;297:538-42.

24. Pruzanski W, Shumak KH. Biologic activity of cold-reacting autoantibodies (second of two parts). N Engl J Med. 1977;297:583-9.

25. Crisp D, Pruzanski W. B-cell neoplasms with homogeneous cold-reacting antibodies (cold agglutinins). Am J Med. 1982;72:915-22.

26. Berentsen S. Cold agglutinin-mediated autoimmune hemolytic anemia in Waldenstrom's macroglobulinemia. Clin Lymphoma. 2009;9:110-2.

27. Rajkumar SV. Epidemiology, pathogenesis, clinical manifestations and diagnosis of Waldenstrom macroglobulinemia. In: Schrier S, Kyle R, Connor R, editors. UpToDate. Waltham: UpToDate; 2012.

28. Ropper AH, Gorson KC. Neuropathies associated with paraproteinemia. N Engl J Med. 1998;338:1601-7.

29. Whittaker SJ, Bhogal BS, Black MM. Acquired immunobullous disease: a cutaneous manifestation of IgM macroglobulinaemia. Br J Dermatol. 1996;135:283-6.

30. Daoud MS, Lust JA, Kyle RA, Pittelkow MR. Monoclonal gammopathies and associated skin disorders. J Am Acad Dermatol. 1999;40:507-35.

31. Riviere E, Ghiringhelli CB, Peyrot I, Lippa N, Laffitte A, Roger-Schmeltz J, et al. Macroglobulinosis cutis revealing Waldenstrom macroglobulinemia. Rev Med Interne. 2011;32:18-20.

32. Kastritis E, Katoulis A, Terpos E, Panayiotides I, Gavriatopoulopu M, Dimopopoulos M. Schnitzler's syndrome: Increased levels of bone formation and angiogenesis factors are reduced after successful pefloxacin treatment. Clin Lymphoma. 2008;8:359-62.

33. Gad A, Willen R, Carlen B, Gyland F, Wickander M. Duodenal involvement in Waldenström's macroglobulinemia. J Clin Gastroenterol. 1995;20:174-6.

34. Morel-Maroger L, Basch A, Danon F, Verroust P, Richet G. Pathology of the Kidney in Waldenström's macroglobulinemia. Study of sixteen cases. N EnglJ Med. 1970;283:123-9.

35. Gertz M, Kyle R, Noel P. Primary systemic amyloidosis: a rare complication of immunoglobulin M monoclonal gammopathies and Waldenstrom's macroglobulinemia. J Clin Oncol. 1993;11:914-20.

36. Gertz MA, Kyle RA. Amyloidosis with IgM monoclonal gammopathies. Semin Oncol. 2003;30:325-8. 
37. Moyner K, Sletten K, Husby G, Natvig JB. An unusually large (83 amino acid residues) amyloid fibril protein AA from a patient with Waldenström's macroglobulinaemia and amyloidosis. Scand J Immunol. 1980;11:549-54.

38. Shah IA, Netto D, Ashfaq R, Krieger C. Waldenström's macroglobulinemia associated with generalized AA-amyloidosis. Int J Surg Pathol. 1993;1:123-7.

39. Gardyn J, Schwartz A, Gal R, Lewinski U, Kristt D, AM. C. Waldenström's macroglobulinemia associated with AA amyloidosis. Int J Hematol. 2001 74:76-8.

40. Hunter ZR, Manning RJ, Hanzis C, Ciccarelli BT, Ioakimidis L, Patterson $\mathrm{CJ}$, et al. IgA and IgG hypogammaglobulinemia in Waldenstrom's macroglobulinemia. Haematologica. 2010;95:470-5.

41. Singh A, Eckardt KU, Zimmermann A, Götz KH, Hamann M, Ratcliffe PJ, et al. Increased plasma viscosity as a reason for inappropriate erythropoietin formation. J Clin Invest. 1993;91:251-6.

42. Roux S, Fermand JP, Brechignac S, Mariette X, Kahn MF, Brouet JC. Tumoral joint involvement in multiple myeloma and Waldenström's macroglobulinemia -report of 4 cases. J Rheumatol. 1996;23:2175-8.

43. Kaila VL, El-Newihi HM, Dreiling BJ, Lynch CA, Mihas AA. Waldenström's macroglobulinemia of the stomach presenting with upper gastrointestinal hemorrhage. Gastrointest Endosc. 1996;44:73-5.

44. Yasui O, Tukamoto F, Sasaki N, Saito T, Yagisawa H, Uno A, et al. Malignant lymphoma of the transverse colon associated with macroglobulinemia. Am J Gastroenterol. 1997;92:2299-301.

45. Rosenthal JA, Curran WJ, Schuster SJ. Waldenström's macroglobulinemia resulting from localized gastric lymphoplasmacytoid lymphoma. Am J Hematol. 1998;58:244-5.

46. Recine MA, Perez MT, Cabello-Inchausti B, Lilenbaum RC, Robinson MJ Extranodal lymphoplasmacytoid lymphoma (immunocytoma) presenting as small intestinal obstruction. Arch Pathol Lab Med. 2001;125:677-9.

47. Rausch PG, Herion JC. Pulmonary manifestations of Waldenstrom macroglobulinemia. Am J Hematol. 1980;9:201-9.

48. Fadil A, Taylor DE. The lung and Waldenstrom's macroglobulinemia. South Med J. 1998;91:681-5.

49. Veltman GA, van Veen S, Kluin-Nelemans JC, Bruijn JA, van Es LA. Renal disease in Waldenström's macroglobulinaemia. Nephrol Dial Transplant. 1997; $12: 1256-9$

50. Mascaro JM, Montserrat E, Estrach T, Feliu E, Ferrando J, Castel T, et al. Specific cutaneous manifestations of Waldenström's macroglobulinemia. A report of two cases. Br J Dermatol. 1982;106:17-22.

51. Orellana J, Friedman AH. Ocular manifestations of multiple myeloma, Waldenström's macroglobulinemia and benign monoclonal gammopathy. Surv Ophthalmol. 1981;26:157-69.

52. Ettl AR, Birbamer GG, Philipp W. Orbital involvement in Waldenström's macroglobulinemia: ultrasound, computed tomography and magnetic resonance findings. Ophthalmologica. 1992;205:40-5.

53. Civit T, Coulbois S, Baylac F, Taillandier L, Auque J. Waldenström's macroglobulinemia and cerebral lymphoplasmocytic proliferation: Bing and Neel syndrome. Apropos of a new case. Neurochirurgie. 1997;43:245-9.

54. Lin P, Mansoor A, Bueso-Ramos C, Hao S, Lai R, Medeiros LJ. Diffuse large B-cell lymphoma occurring in patients with lymphoplasmacytic lymphoma/ Waldenstrom macroglobulinemia - clinicopathologic features of 12 Cases. Am J Clin Pathol. 2003;120:246-53

55. Feiner HD, Rizk CC, Finfer MD, Bannan M, Gottesman SR, Chuba JV, et al IgM monoclonal gammopathy/Waldenström's macroglobulinemia: a morphological and immunophenotypic study of the bone marrow. Mod Pathol. 1990;3:348-56.

56. San Miguel JF, Vidriales MB, Ocio E, Mateo G, Sánchez-Guijo F, Sánchez $\mathrm{ML}$, et al. Immunophenotypic analysis of Waldenstrom's macroglobulinemia. Semin Oncol. 2003;30:187-95.
57. Pangalis G, Kyrtsonis M-C, Kontopidou F, Siakantaris M, Dimopoulou M, Vassilakopoulos T, et al. Differential diagnosis of Waldenström's macroglobulinemia and other B-Cell disorders. Clin Lymphoma. 2005;5:235-40.

58. Kyle RA, Therneau TM, Rajkumar SV, Offord JR, Larson DR, Plevak MF, et al. A long-term study of prognosis in monoclonal gammopathy of undetermined significance. N Engl J Med. 2002;346:564-9.

59. Kyle RA, Therneau TM, Rajkumar SV, Remstein ED, Offord JR, Larson DR, et al. Long-term follow-up of IgM monoclonal gammopathy of undetermined significance. Blood. 2003;102:3759-64.

60. Morel P, Duhamel A, Gobbi P, Dimopoulos MA, Dhodapkar MV, McCoy J, et al. International prognostic scoring system for Waldenstrom macroglobulinemia. Blood. 2009;113:4163-70.

61. Kastritis E, Kyrtsonis MC, Hadjiharissi E, Symeonidis A, Michalis E, Repoussis $\mathrm{P}$, et al. Validation of the International Prognostic Scoring System (IPSS) for Waldenstrom's macroglobulinemia (WM) and the importance of serum lactate dehydrogenase (LDH). Leuk Res. 2010;34:1340-3.

62. Treon SP. How I treat Waldenstrom macroglobulinemia. Blood. 2009;114:2375-85.

63. Dimopoulos MA, Gertz MA, Kastritis E, Garcia-Sanz R, Kimby EK, LeBlond V, et al. Update on treatment recommendations from the Fourth International Workshop on Waldenström's macroglobulinemia. J Clin Oncol. 2009;27:120-6.

64. Vijay A, Gertz M. Current treatment options for Waldenström macroglobulinemia. Clin Lymphoma. 2008;8:219-29.

65. Dimopoulos MA, Anagnostopoulos A, Kyrtsonis MC, Zervas K, Tsatalas C, Kokkinis G, et al. Primary treatment of Waldenström macroglobulinemia with dexamethasone, rituximab, and cyclophosphamide. J Clin Oncol. 2007;25:3344-9.

66. Jaglowski SM, Alinari L, Lapalombella R, Muthusamy N, Byrd JC. The clinical application of monoclonal antibodies in chronic lymphocytic leukemia. Blood. 2010;116:3705-14.

67. Smith MR. Rituximab (monoclonal anti-CD20 antibody): mechanisms of action and resistance. Oncogene. 2003;22: 7359-68.

68. Treon SP, Hansen M, Branagan AR, Verselis S, Emmanouilides C, Kimby E, et al. Polymorphisms in Fc'RIIIA (CD16) receptor expression are associated with clinical response to rituximab in Waldenström's macroglobulinemia. J Clin Oncol. 2005;23:474-81.

69. Ghobrial IM, Fonseca R, Greipp PR, Blood E, Rue M, Vesole DH, et al. Initial immunoglobulin $\mathrm{M}$ 'flare' after rituximab therapy in patients diagnosed with Waldenstrom macroglobulinemia. Cancer. 2004;101:2593-8.

70. Dimopoulos MA, Zervas C, Zomas A, Kiamouris C, Viniou NA, Grigoraki $\mathrm{V}$, et al. Treatment of Waldenström's macroglobulinemia with rituximab. J Clin Oncol. 2002;20:2327-33.

71. Treon SP, Branagan AR, Hunter Z, Santos D, Tournhilac O, Anderson KC. Paradoxical increases in serum IgM and viscosity levels following rituximab in Waldenstrom's macroglobulinemia. Ann Oncol. 2004;15:1481-3.

72. Issa GC, Ghobrial IM, Roccaro AM. Novel agents in Waldenström macroglobulinemia. Clin Invest (Lond). 2011;1:815-24.

73. Owen RG, Kyle RA, Stone MJ, Rawstron AC, Leblond V, Merlini G, et al. Response assessment in Waldenstrom macroglobulinaemia: update from the $6^{\text {th }}$ International Workshop. Br J Haematol. 2013;160:171-6.

74. Ciccarelli BT, Yang G, Hatjiharissi E, Ioakimidis L, Patterson CJ, Manning RJ, et al. Soluble CD27 is a faithful marker of disease burden and is unaffected by the rituximab-induced IgM flare, as well as by plasmapheresis, in patients with Waldenstrom's macroglobulinemia. Clin Lymphoma. 2009;09:56 AM-8.

75. Itzykson R, Le Garff-Tavernier M, Katsahian S, Diemert MC, Musset L, Leblond V. Serum-free light chain elevation is associated with a shorter time to treatment in Waldenstrom's macroglobulinemia. Haematologica. 2008;93:793-4.

76. Fonseca R, Hayman S. Waldenström macroglobulinaemia. Br J Haematol. 2007; 138:700-20. 